\title{
Keterampilan Pemecahan Masalah Siswa Pada Materi Listrik Arus Searah di Masa Pembelajaran Jarak Jauh
}

\author{
Ken Ayu Citra*, Nehru, Febri Berthalita Pujaningsih, Cicyn Riantoni \\ Program Studi Pendidikan Fisika, Universitas Jambi \\ *Email: ken.ayucitra29@gmail.com
}

Received: 18 Mei 2021; $\quad$ Accepted: 26 Juli 2021; $\quad$ Published: 22 Oktober 2021

DOI: http://dx.doi.org/10.29303/jpft.v7i2.2663

\begin{abstract}
- this study aims to determine the description of students' problem solving skills on direct current electricity in physics subjects held through Distance Learning (PJJ). This type of research is quantitative research. The research subjects were 26 students of class XII at SMA Negeri 1 Jambi City. Data collection was carried out using a problem-solving skill test for direct current electricity which consisted of 6 essay questions. The data obtained were analyzed using descriptive statistics. From the results of data analysis, it is known that the lowest score is 14 and the highest score is 46, and the average student problem solving skills test results are 37. Meanwhile, the percentage of each stage of student problem solving is classified as very bad. Thus, it is concluded that the problem solving skills of class XII MIPA 7 students on direct current electricity through PJJ are classified as very low criteria.
\end{abstract}

Keywords: problem solving skills; direct current electricity.

\section{PENDAHULUAN}

Corona Virus Disease 2019 atau yang lebih sering disebut sebagai Covid-19 merupakan pandemi yang tengah melanda dunia pada saat ini. Menurut Magdalena et al. (2020) mengungkapkan bahwa Covid-19 pertama kali ditemukan dan menyebar di Kota Wuhan, China pada penghujung Desember 2019. Menurut Quyumi \& Alimansur (2020) menyatakan bahwa penularan virus ini terjadi secara droplet atau melalui percikan saliva. Hal ini menyebabkan penyebaran Covid-19 terjadi dengan sangat cepat, sehingga menyebar ke berbagai negara, tak terkecuali Indonesia.

Penyebaran Covid-19 di tanah air, telah terjadi di 34 provinsi yang ada di Indonesia. Kondisi demikian, menyebakan pemerintah mengeluarkan berbagai kebijakan yang bertujuan untuk memutus rantai penyebaran virus ini. Salah satu kebijakan yang dikeluarkan pemerintah Indonesia yaitu terkait social distancing dan physical distancing. Menurut Darsono et al. (2020) memaparkan bahwa penerapan kedua kebijakan tersebut dilakukan pada berbagai sektor, termasuk sektor pendidikan. Hal ini menyebakan pembelajaran yang umumnya dilakukan secara tatap muka di ruang kelas, digantikan menjadi Pembelajaran Jarak Jauh (PJJ).

Menurut Prawiyogi (2020) mengungkapkan bahwa PJJ merupakan pembelajaran menggunakan suatu media yang memungkinkan interaksi antara pengajar dan peserta didik. Dengan syarat bahwa antara pengajar dan peserta didik tidak bertatap muka secara langsung atau keduanya berada di tempat yang berbeda. Pemberlakuan PJJ jelas merupakan sebuah tantangan tersendiri baik bagi guru dan siswa. Guru dan siswa diminta agar dapat beradaptasi dengan perubahan proses pembelajaran, sekaligus diharapkan agar tetap mampu mencapai tujuan atau kompetensi pembelajaran sekalipun proses pembelajaran yang dilakukan mengalami perubahan.

Menurut Cahyani \& Setyawati (2016) menyatakan bahwa salah satu tujuan dalam pembelajaran di Indonesia dari aspek kurikulum adalah mewujudkan keterampilan pemecahan masalah dalam diri siswa. Selaras dengan pendapat Rahmawati \& Ika 
(2020) yang mengungkapkan bahwa keterampilan pemecahan masalah merupakan hasil belajar utama dari proses pembelajaran itu sendiri. Keterampilan pemecahan masalah adalah kemampuan fundamental yang wajib dimiliki oleh setiap siswa.

Keterampilan pemecahan masalah ialah kemampuan yang dimiliki seseorang untuk menyelesaikan suatu persoalan atau suatu masalah yang sedang dihadapinya. Menurut Jayadiningrat \& Ati (2018) mengungkapkan bahwa peran keterampilan pemecahan masalah yaitu agar seseorang mampu menyelesaikan suatu persoalan atau masalah. Menurut Nurwahyuningsih, et al. (2019) menyatkan bahwa keterampilan pemecahan masalah adalah jenis keterampilan yang sangat diperlukan para siswa agar mampu menyelesaikan bergagai masa-lah dalam tugas dan kehidupan sehari-hari.

Menurut Faisal, et al. (2020) menyatakan bahwa keterampilan pemecahan masalah sangat dibutuhkan dalam setiap mata pelajaran yang diajarkan kepada siswa, terutama mata pelajaran fisika yang diajarkan di jenjang Sekolah Menenagah Atas (SMA). Salah satu materi yang diajarkan mata pelajaran fisika di jenjang SMA adalah materi listrik arus searah. Dalam Permendikbud Nomor 21 Tahun 2016 tercantum kalimat pada kompetensi fisika SMA yaitu "menganalisis konsep, prinsip, dan hukum kelistrikan, kemagnetan, dan fisika modern serta me-nerapkan metakognisi dalam menjelaskan fenomena alam dan penyelesaian masalah kehidupan".

Berdasarkan pada penjelasan di atas dan fakta bahwa keterampilan pemecahan masalah merupakan keterampilan yang krusial. Oleh sebab itu, tujuan penelitian ini yaitu untuk mengetahui gambaran keterampilan pemecahan masalah siswa pada materi listrik arus searah dalam mata pelajaran fisika yang diselenggaran melalui Pembelajaran Jarak Jauh (PJJ).

\section{METODE PENELITIAN}

Jenis penelitian yang dilakukan merupakan penelitian kuantitatif. Penelitian dilakukan di SMA Negeri 1 Kota Jambi, dengan teknik sampling berupa purposive sampling. Di mana peneliti menggunakan kriteria-kriteria tertentu untuk menentukan sampel penelitian. Kriteria pemilihan sampel berupa siswa kelas XII MIPA yang telah mempelajari materi listrik arus searah dan bersedia menjadi subyek/sampel dalam penelitian ini. Sampel penelitian berupa 26 siswa kelas XII MIPA di SMA Negeri 1 Kota Jambi semester genap tahun ajaran 2021.

Teknik pengumpulan data menggunakan soal tes keterampilan pemecahan masalah materi listrik arus searah. Soal keterampilan pemecahan masalah yang digunakan terdiri atas 6 buah soal essay yang diadaptasi dari tesis Riantoni (2017) dan divalidasi menggunakan validitas ahli. Hasil tes siswa akan diskor menggunakan indikator tahap pemecahan masalah hasil penelitian Docktor et al. (2016), dengan indikator yaitu (1) useful description, (2) physics approach, (3) specific application of physic, (4) mathematical procedures dan (5) logical progress. Data yang diperoleh dianalisis menggunakan pengujian statistika deskriptif. Data juga akan dianalisis untuk mengetahui presentase tiap tahap pemecahan masalah yang dimiliki siswa. Adapun rumus presentase bersumber dari Mustofa \& Rusdiana (2016) sebagai berikut.

$$
P_{x}=\frac{R_{x}}{n \cdot S_{x}} \times 100 \%
$$

Presentase diberikan kriteria sesuai dengan tabel berikut.

Tabel 1. Kriteria Presntase Tahap Keterampilan Siswa

\begin{tabular}{cc}
\hline Persentase & Kriteria \\
\hline $\mathbf{8 0}<\mathbf{P}_{\mathbf{x}} \leq \mathbf{1 0 0}$ & Sangat tinggi (ST) \\
$\mathbf{6 0}<\mathbf{P}_{\mathbf{x}} \leq \mathbf{8 0}$ & Tinggi (T) \\
$\mathbf{4 0}<\mathbf{P}_{\mathbf{x}} \leq \mathbf{6 0}$ & Cukup (C) \\
\hline
\end{tabular}




\begin{tabular}{cc}
\hline Persentase & Kriteria \\
\hline $\mathbf{2 0}<\mathbf{P}_{\mathbf{x}} \leq \mathbf{4 0}$ & Rendah (R) \\
$\mathbf{P}_{\mathbf{x}} \leq \mathbf{2 0}$ & Sangat Rendah (SR) \\
\hline & (Mustofa \& Rusdiana, 2016)
\end{tabular}

\section{HASIL DAN PEMBAHASAN}

Hasil

Hasil analisis data tes keterampilan pemecahan masalah siswa menggunakan statistika deskriptif disajikan dalam tabel berikut.

Tabel 2. Parameter Statistika Deskriptif

\begin{tabular}{cc}
\hline Parameter & Nilai \\
\hline N & 26 \\
Minimum & 14 \\
Maksimum & 46 \\
Range & 32 \\
Rata-Rata & 37 \\
Standar Deviasi & 11 \\
\hline
\end{tabular}

Selanjutnya, analisis presentase tiap tahap pemecahan masalah siswa disajikan dalam diagram batang berikut.

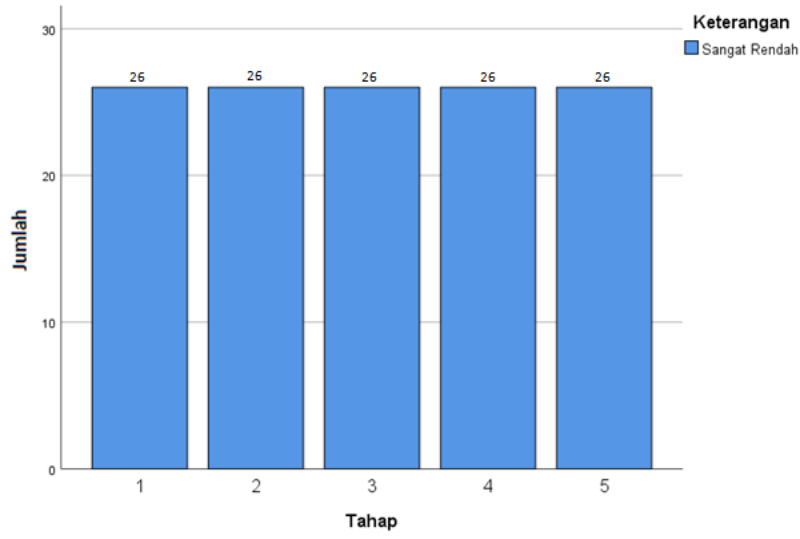

Gambar 1. Kriteria Tahap Pemecahan Masalah Siswa

\section{Pembahasan}

Berdasarkan Tabel 2. diketahui bahwa hasil tes keterampilan pemecahan masalah siswa memiliki rata-rata yang rendah. Tabel 2. sejalan dengan diagram yang ditampilan pada Gambar 1. Dari diagram batang tersebut, diketahui bahwa untuk tahap pemecahan masalah (1) useful description,
(2) physics approach,
(3) specific application of physic, (4) mathematical procedures dan (5) logical progress bagi ke 26 siswa memiliki kriteria sangat rendah. Demikian, tidak terdapat satu orang pun siswa dengan kriteria sangat tinggi, tinggi, cukup bahkan dengan kriteria rendah untuk setiap tahap pemecahan masalah tersebut.

Tahap pemecahan masalah siswa yang sangat rendah akan membuat jawaban siswa terhadap suatu persoalan cenderung tidak tepat. Hal ini, tentunya berdampak pada keterampilan pemecahan masalah siswa. Di mana keterampilan pemecahan masalah siswa juga akan menjadi sangat rendah dikarenakan tahap pemecahan masalah siswa yang sangat rendah tersebut.

Hasil penelitian yang diperoleh sesuai dengan hasil penelitian sebelumnya yang dilakukan oleh Mustofa \& Rusdiana (2016) dengan hasil berupa keterampilan pemecahan masalah siswa masih kurang. Sangat rendahnya keterampilan pemecahan masalah siswa pada materi listrik arus searah dapat disebabkan oleh kurangnya pemahaman siswa terhadap materi. Hal ini sejalan dengan pendapat Dewati et al. (2019) yang menyatakan bahwa penyebab utama kesukaran siswa dalam pemecahan masalah disebabkan oleh lemahnya pema-haman siswa terhadap konsep dan hukum fisika, di mana hal ini akan berujung pada kesalahan konsep. Selain itu, menurut Azizah et al. (2016) mengungkapkan bahwa rendahnya keterampilan pemecahan masa-lah siswa dikarenakan saat menghadapi suatu persoalan, siswa akan mencoba menyelesaikan persoalan tersebut langsung menggunakan persamaan matematis, tanpa terlebih dahulu melakukan pemahaman konsep.

Berlandaskan penjelasan tersebut, terlihat bahwa rendahnya keterampilan pemecahan masalah dapat disebabkan oleh lemahnya pemahaman siswa terhadap konsep materi arus searah itu sendiri. Lemahnya pemahaman siswa terhadap 
konsep listrik arus searah dapat dipengaruhi oleh tingkat efektifnya proses PJJ yang tengah diterapkan saat ini. Hal ini sejalan dengan hasil penelitian Mahardini (2020) yang menyatakan bahwa pelaksanaan PJJ menyebabkan rendahnya keaktifan siswa dalam proses pembelajaran, menyebabkan kesukaran bagi guru dalam menjelaskan materi khususnya materi dengan persamaan fisika, serta menyebabkan kesulitan bagi siswa dalam memahami materi tersebut. Selain itu, penyebab lainnya berupa siswa yang cenderung langsung menyelesaikan persoalan menggunakan persamaan matematis, hal ini menunjukkan bahwa siswa dalam menyelesaikan suatu persoalan tidak melakukannya secara sistematis atau dengan cara acak yang cenderung men-duga-duga persamaan yang tepat untuk menyelesaikan persoalan yang dihadapinya.

\section{PENUTUP}

Adapun kesimpulan yang dapat ditarik dari pembahasan yaitu diketahui bahwa keterampilan pemecahan masalah siswa 26 siswa kelas XII di SMA Negeri 1 Kota Jambi pada materi listrik arus searah masih sangat rendah. Hal ini dibuktikan dengan sangat rendahnya presentase untuk tiap tahap pemecahan masalah yang dilakukan siswa. Rendahnya keterampilan pemecahan masalah siswa dapat dikarenakan oleh lemahnya pemahaman siswa terhadap konsep, serta dikarenakan siswa yang memecahkan masalah tidak secara sistematis. Hal-hal demikian, dapat dikarenakan proses PJJ yang kurang efektif.

Sedangkan, saran yang dapat diberikan peneliti yaitu, agar PJJ dapat berlangsung lebih aktif dan guru dalam proses pembelajaran lebih memperhatikan kompetensi keterampilan pemecahan masalah dengan cara menerapkan model, metode, strategi atau teknik pembelajaran yang mampu membantu tercapainya kompetensi ini dengan baik.

\section{REFERENSI}

Azizah, R., Yuliati, L., \& Latifah, E. (2016). Kemampuan Pemecahan Masalah Melalui Pembelajaran Interactive Demonstration Siswa Kelas X SMA pada Materi Kalor. Jurnal Pendidikan Fisika dan Teknologi, 2 (2), 55-60, dari https://dx.doi.org/10.29303/jpft.v2i2 .289 .

Cahyani, H., \& Setyawati, R. W. (2016). Pentingnya Peningkatan Kemampuan Pemecahan Masalah Melalui PBL untuk Mempersiapkan Generasi Unggul Menghadapi MEA. Makalah disajikan dalam Seminar Nasional Matematika X, Universitas Negeri Semarang, Semarang. Diperoleh dari https://journal.unnes.ac.id/sju/index. $\mathrm{php} / \mathrm{prisma} /$ article/view/21635.

Darsono, H., Fitri, a. N., Rahardjo, B., Imanuela, M. Z., \& Lasambouw C. M. (2020). Efektifitas Pembe-lajaran Jarah Jauh Saat Pendemi Covid-19 (Kajian di Politeknik Bandung. Makalah disajikan dalam The $11^{\text {th }}$ Industrial Research Workshop and National Seminar, Bandung. Diperoleh dari https://jurnal.polban.ac.id/ojs3.1.2/proceeding/article/view/2190.

Dewati, M., Suparmi, A., Sunarsono, W., Sukarmin, \& Cari, C. (2019). Implementasi Multiple Representation Pada Rangkaian Listrik DC Sebagai Upaya Meningkatkan Problem Solving Skills. Makalah disajikan dalam Seminar Fisika Nasional dan Aplikasinya, Universitas Sebelas Maret, Solo. Diperoleh dari https://doi.org/10.20961/prosidingsn fa.v4i0.35927.

Docktor, J. L., Domfeld, J., Frodermann, E., Heller, K.., Hsu, L., Jackson, K. A., 
... Yang, J. (2016). Assessing Student Written Problem Solution: A Problem-Solving Rubric with Application to Introductory Physics. American Physical Society, 12 (1), 118 , from http://dx.doi.org/10.1103/PhysRevP hysEducRes.12.010130.

Faisal, Rokhmat, J., \& Ardhuha, J. (2020). Kemampuan Pemecahan Masalah Dan Kreativitas Peserta Didik Dengan Pendekaran Kausalistik Scaffolding. Jurnal Pendidikan Fisika dan Teknologi, 6(1), 107-113, dari

https://jurnalfkip.unram.ac.id/index. php/JPFT/article/view/1771.

Jayadiningrat, M. G. , \& Ati, E. K. (2018). Peningkatan Keterampilan Pemecahan Masalah Melalui Model Pembelajaran Problem Based Learning (PBL) Pada Mata Pelajaran Kimia. Jurnal Pendidikan Kimia Indonesia, 2 (1), 1-10, dari http://dx.doi.org/10.23887/jpk.v2i1. 14133.

Magdalena, I., Erdian, A. E., \& Marcelino, R. (2020). Analisis Efektivitas Pembelajaran Jarak Jauh Di Masa Pendemi Covid 19 Di SD Negeri Poris Pelawad 03 Kota Tanggerang. Jurnal Pendidikan dan Sains, 2 (2), 300-313,

dari https://doi.org/10.36088/bintang.v2i 2.1054 .

Mahardini, M. M. A. (2020). Analisis Situasi Penggunaan Google Classroom Pada Pembelajaran Daring Fisika. Jurnal Pendidikan Fisika, 3(2), 215-224, dari

https://www.ojs.fkip.ummetro.ac.id/ index.php/fisika/article/viewFile/31 02/1443.

Mustofa, M. H., \& Rusdiana, D. (2016). Profil Kemampuan Pemecahan Masalah Siswa pada Pembelajaran Gerak Lurus. Jurnal Penelitian dan Pendidikan Pengembangan Fisika, 2 (2), 15-22, dari https://doi.org/10.21009/1.02203.
Nurwahyuningsih, Harjono, A., \& Rahayu, S. (2019). Pemecahan Masalah Usaha dan Energi dengan Model Pembelajaran Berbasis Proyek Ditinjau Dari Keterampilan Berpikir Kritis Peserta Didik. Jurnal Pendidikan Fisika dan Teknologi, 5(2), 253-261, dari https://jurnalfkip.unram.ac.id/index. $\mathrm{php/JPFT/article/view/1325/pdf.}$

Prawiyogi, A. G. (2020). Efektifitas Pembelajaran Jarak Jauh Terhadap Pembelajaran Siswa di SDIT Purwakarta. Jurnal Pendidikan Dasar, 94-101, dari https://doi.org/10.21009/10.21009/J PD.081.

Quyumi, E. R, \& Alimansur, M. (2020). Upaya Pencegahan dengan Kepatuhan Dalam Pencegahan Penularan COVID-19 Pada Relawan COVID. JPH, 4 (1), 81-87, dari https://ejournal.unair.ac.id/JPHRECODE/art icle/download/21792/pdf.

Rahmawati, A. S., \& Ika, Y. E. (2020). Perbedaan Keefektifan Model Pembelajaran Kooperatif Tipe STAD (Student Teams Acievement Division) dan Jigsaw Terhadap Kemampuan Pemecahan Masalah Pada Pembelajaran Fisika. Jurnal Pendidikan Fisika dan Teknologi, 6(1), 162-168, dari https://jurnalfkip.unram.ac.id/index. php/JPFT/article/view/1661/pdf.

Riantoni, C. (2017). Pemecahan Masalah Materi Listrik Dinamis Mahasiswa S1 Pendidikan Fisika Universitas Negeri Jambi Pada Pembelajaran Inkuiri Terbimbing dengan PhET Interactive Simulation. Tesis. Malang: Universtas Negeri Malang. 